\title{
Additive Positive Effects of Pollination on Bt and Non-Bt Soybean Cultivars by Honey Bee and Native Flower-Visiting
}

\author{
Fabiola de Oliveira ${ }^{1} \&$ Marcos Gino Fernandes ${ }^{2}$ \\ ${ }^{1}$ Postgraduate Program in Entomology and Biodiversity Conservation, Federal University of Grande Dourados, \\ Brazil \\ ${ }^{2}$ Faculty of Environmental and Biological Science, Federal University of Grande Dourados, Brazil \\ Correspondence: Marcos Gino Fernandes, Faculty of Environmental and Biological Science, Federal University \\ of Grande Dourados, Avenida Guaicurus, km 12, Unidade II-Caixa Postal: 364, CEP: 79.804-970, Brazil. \\ E-mail: marcosfernandes@ufgd.edu.br
}

Received: June 9, 2019

Accepted: August 2, $2019 \quad$ Online Published: December 15, 2020

doi:10.5539/jas.v13n1p157

URL: https://doi.org/10.5539/jas.v13n1p157

\begin{abstract}
In addition to the increase in the number of pods produced, a well-conducted pollination also contributes to an increase in the number of grains per pod, improves the quality of the grains and seeds, and renders the grain ripening more uniform, thus, increasing the production at harvest. The objective of the present study was to quantify the benefits of flower-visiting insects in soybean production. The experiment was conducted with two soybean cultivars, one Bt and one non-Bt. During the flowering period, 150 plants of each cultivar were randomly selected, yielding 25 replicates (three plants per replicate) with free access to flower visitors, and another 25 replicates (also with three plants per replicate) that flower visitors could not access. During the flowering period, 549 specimens of flower-visiting insects were found in both cultivars, divided into eight orders, 30 families, and 92 species. The most abundant species were Apis mellifera (Linnaeus) (Hymenoptera: Apidae), Musca sp.1 (Linnaeus) (Diptera: Muscidae), and Lagria villosa (Fabricius) (Coleoptera: Tenebrionidae). In the treatment with flower visitors, grain weight increased by $84.22 \%$ in Bt cultivar and by $202.52 \%$ in non-Bt cultivar, compared with the area without the presence of flower visitors. The increase in the number of pods in $\mathrm{Bt}$ and non-Bt cultivars was $45.72 \%$ and $101.25 \%$ respectively, in the area open to flower visitors. The high increase in grain yield and number of pods observed in the area with free access to pollinator insects emphasizes the high importance of the pollination service performed by flower visitors to the soybean crop.
\end{abstract}

Keywords: Glycine max, pollinators, soybean production

\section{Introduction}

Soybean (Glycine max (Linnaeus) Merrill) is a very important crop worldwide; it is one of the main agricultural commodities in Brazil - its second largest producer in the world — where the area cultivated with this legume has increased continuously (Agrianual, 2009; Embrapa, 2015). However, several species of arthropods induce damage to this crop, reducing yield and grain and seed quality (Sosa-Gomés et al., 2006).

Heavy application of pesticides to control crop pests can adversely affect beneficial organisms, leave chemical residues in food, and cause environmental pollution. Despite the clear benefits of the use of pesticides in agriculture - avoiding losses associated with insect attack - there is a persistent need to develop additional alternatives or technologies that allow the rational use of these products, and provide adequate protection for a sustainable production of food, feed, and fiber (Sharma et al., 2000).

Genetic engineering has resulted in the creation of genetically modified (GM) varieties of many cultivars that express the Bacillus thuringiensis (Berliner, 1915) (Bacillales: Bacillaceae) (Bt) toxin. Recombinant DNA techniques allowed the insertion of this bacterial gene into plants, which then start producing Cry proteins (among other products of relatively low commercial value). The ingestion of the Cry protein by the insects triggers an osmotic rupture of their digestive tract epithelial cells, culminating in their death before they are able to damage the crop (Hof \& Whitely, 1989; Sankula, 2006; Andow, 2008).

B. thuringiensis has been the most successful organism among a group of taxa identified for the use of their genes in plant genetic transformation for pest control (Charles et al., 1996; Hilder \& Boulter, 1999). 
In Brazil, technologies or combined "events" for GM soybean, MON 87701 and MON 89788, conferring resistance to insects and tolerance to the herbicide glyphosate, respectively, were commercially released in August 2010 (CTNBio, 2010).

The technology known commercially as Intacta RR2 PRO, containing the events MON 87701 and MON 89788, confers resistance to the main soybean foliage-stripping caterpillars, such as velvetbean caterpillar Anticarsia gemmatalis (Hübner) (Lepidoptera: Noctuidae), soybean looper Chrysodeixis includens (Walker) (Lepidoptera: Noctuidae), Rachiplusia nu (Guenée) (Lepidoptera: Noctuidae), and tortrix moth Crocidosema aporema (Walsingham) (Lepidoptera: Noctuidae). These are the target pests of the Bt technology, for which insecticide application is not necessary (Monsanto, 2012). However, it is still necessary to monitor and control aphids and other non-targeted caterpillars.

Pollination is currently a key production factor for the worldwide soybean production. A well-conducted pollination not only increases the number of pods produced, but also contributes to an increase in the number of grains per pod, improves the quality of the grains and seeds formed, decreases grain malformation rates, increases the contents of oil and other substances extracted from grains and seeds, shortens the cycle of some cultivars, and even harmonizes grain maturation, thereby increasing crop yields (Free, 1993; McGregor, 1976; Williams et al., 1991; Freitas, 1997; Nogueira-Couto, 1994, 1998).

Entomophilic pollination is responsible for increases of up to $58.58 \%, 82.31 \%, 57.73 \%$, and $61.38 \%$ in pod number, seed number, seed production and pod amount, respectively, when comparing plants with free visitation of insects against plants where cross-pollination was not allowed (Chiari et al., 2005). The number of non-pollinated flowers in the soybean crop might also be quite high - in some cultivars, more than $75 \%$ of the flowers did not develop seeds (Free, 1993), due to poor entomophilic pollination.

Among the various pollinators, insects stand out because they are abundant in nature and adjust perfectly to different flower structures (Free, 1993). Apis mellifera (Linnaeus) (Hymenoptera: Apidae) is known as a highly efficient pollinator-accounting for about $80 \%$ of the total entomophilic pollination in several crops (McGregor, 1976). Studies on the effect of pollination on soybean crops highlight the great importance of insect pollination for this crop (Moreti, 1998). Studies with the introduction of A. mellifera colonies near production fields observed an increase in soybean production of $18.09 \%$ compared with areas where hives had not been set up (Milfont et al., 2013).

The natural abscission of soybean flowers can reach up to $80 \%$, depending on the cultivar and environmental conditions (Carlson, 1973; Justiniano et al., 2014). The presence of pollinators can drastically reduce this rate; average values of $53.31 \%$ and $82.90 \%$ for soybean flower abscission were reported when A. mellifera bees were present and absent, respectively (Chiari, 2005).

The present study was conducted with the objective of evaluating, through quantification, the benefits of flower-visiting insects for the production of $\mathrm{Bt}$ and non-Bt soybean.

\section{Materials and Methods}

\subsection{Experimental Area}

The experiment was carried out at the Experimental Farm of the Federal University of Grande Dourados $\left(22^{\circ} 14^{\prime} 20.51^{\prime \prime} \mathrm{S}, 54^{\circ} 59^{\prime} 58.4^{\prime \prime} \mathrm{W}\right.$, altitude of $\left.394 \mathrm{~m}\right)$, in the city of Dourados-MS, Brazil. The sampling area comprised two field plots of $1.0 \mathrm{ha}^{-1}$ each, one seeded with the cultivar DM 6563 Intacta event MON $87701 \times$ MON 89788 (Bt transgenic), and the other with the cultivar BMX Potência RR event M 8360 RR (non-Bt transgenic). On November 5, 2014, the sowing of both cultivars was carried out. During the sampling (item 2.3 Monitoring) period, the presence of pests did not reach a level that required spraying of insecticides.

\subsection{Data Collection}

The analyzed variables were the mass of grains produced per plant, the number of pods per plant, and the height of the plants in both crops, divided into an uncovered area with, and a covered area without, the free visitation of flower-visiting insects.

Uncovered area: 25 replicates per cultivar, with three plants per replicate, were randomly assigned. The replicates were marked with stakes and ribbons, and were exposed to the natural presence of the flower-visiting insects. Afterwards, the heights of the plants were measured and they were cut at the ground level. The samples were taken to the laboratory, where the number of pods formed and the mass of the grains in each third of the plant were recorded for each replicate.

Covered area: 25 replicates per cultivar, with three plants per replicate, were randomly assigned. Each replicate 
(set of three plants) was covered with a metal structure covered with voile. These 'cages' were placed in the two sampling areas just before the beginning of the reproductive period, and remained there until the end of plant flowering. Subsequently, the same data as in the uncovered area were taken - plant height, total pods, and mass of grains produced in each replicate.

In addition to the sampling areas, an A. mellifera beehive (containing approximately 50,000 individuals) was placed 20 meters from the experimental field plots to facilitate the presence of this species for pollinating the crop.

Data on the development and production of the plants were recorded when the plants were fully developed in terms of reproduction (i.e., suitable for harvesting). The pods of each replicate were collected in full and counted, in order to determine the vertical distribution of the production in the lower, middle, and upper thirds of each plant. The grains present in each pod of each replicate were removed, dried in a drying oven $(64 \mathrm{~L})$, and weighed, separated by plant sections. In addition, each of the three plants that composed each replicate had their height from the ground level measured with a ruler.

The mean seed weight of each plant third, in each treatment and cultivar, was evaluated by analytical weighing of the seeds, obtaining an average value per plant portion (low, medium, and high height), by treatment (uncovered or covered area), and by cultivar (Bt soybean and non-Bt soybean).

\subsection{Monitoring}

The soybean crop was monitored during the flowering period (December 26, 2014 to January 11, 2015). The sampling method was adapted from Pires et al. (2006), which involved the use of an entomological net. Flower-visiting insects were collected every three or four days, totaling four samplings, to determine their abundance and diversity.

\subsection{Data Analysis}

To analyze seed production, we used complete randomized design experiments with two treatments (with/without voile) and 25 replicates. Data were subjected to analysis of variance. For the comparison of the means for each tested variable, after the Kolmogorov-Smirnov and Shapiro-Wilk tests had been applied to evaluate normality of plant height and production data, Student's $t$-test was employed at a $5 \%$ significance level to compare treatments with and without voile.

\section{Results}

During the flowering period of the cultivars, 549 flower-visiting insect specimens were collected - belonging to eight orders, 30 families, and 92 species — of which, 279 individuals were present in the Intacta (Bt) cultivar, and 270 were collected from the Potência (non-Bt) cultivar flowers. Representatives of the family Apidae (Hymenoptera) were the most abundant. The species A. mellifera was the most abundant in both cultivars (this was expected due to the proximity of the hive), followed by Musca sp.1 (Linnaeus, 1758) (Diptera: Muscidae) and Lagria villosa (Fabricius, 1783) (Coleoptera: Tenebrionidae).

There was a significant increase in production for the two cultivars evaluated in the treatment exposed to insect visitors, as the grain yield in samples covered with cages was lower (Table 1). Grain weight increased by $84.22 \%$ (from $8.1448 \mathrm{~g} /$ replicate in the covered area to $15.0113 \mathrm{~g}$ in the uncovered area), considering the total production of the Intacta cultivar, and by $202.52 \%$ (from $2.0800 \mathrm{~g}$ in the treatment with voile to $6.2865 \mathrm{~g}$ in the uncovered area treatment) in the Potência cultivar. Intacta samples exposed to flower-visiting insects exhibited an almost two-fold increase in the average production per sample (increase of $84.22 \%$ ), while the samples of the Potência cultivar not covered by cages, and consequently, in contact with visiting insects yielded a roughly three-fold increase in production per sample (202.52\%) (Table 1). When considering the increase in both cultivars together, samples protected from the visitation of flower visitors presented an average yield of $5.1131 \mathrm{~g}$. An increase of $108.26 \%$ in the uncovered samples was observed, since the average total production of these samples was $10.6489 \mathrm{~g} / \mathrm{sample}$. 
Table 1. Soybean yield under two pollination treatments: with free visitation of insects (open area), and without visitation of insects (caged area)

\begin{tabular}{|c|c|c|c|c|}
\hline \multirow{2}{*}{ Part of the plant } & \multirow{2}{*}{ Cultivars } & \multicolumn{2}{|c|}{ Grain mass (g) } & \multirow{2}{*}{ Increment $(\%)$} \\
\hline & & Caged area & Open area & \\
\hline \multirow{3}{*}{ Lower Third } & Intacta & 5.2905 & $7.1034^{\mathrm{ns}}$ & 45.73 \\
\hline & Potência & 1.1297 & $2.9970 *$ & 165.29 \\
\hline & TOTAL & 3.2101 & $5.0502 *$ & 57.32 \\
\hline \multirow{3}{*}{ Middle Third } & Intacta & 9.2987 & $20.0601 *$ & 115.73 \\
\hline & Potência & 2.4318 & $9.1171 *$ & 274.91 \\
\hline & TOTAL & 5.8652 & $14.5886^{*}$ & 148.73 \\
\hline \multirow{3}{*}{ Upper Third } & Intacta & 9.8554 & $17.8706^{*}$ & 81.32 \\
\hline & Potência & 2.6726 & $6.7454^{*}$ & 152.39 \\
\hline & TOTAL & 6.2640 & $12.3080^{*}$ & 96.48 \\
\hline \multirow{3}{*}{ Total } & Intacta & 8.1482 & $15.0114^{*}$ & 84.22 \\
\hline & Potência & 2.0780 & $6.2865^{*}$ & 202.52 \\
\hline & Total & 5.1131 & $10.6489 *$ & 108.26 \\
\hline
\end{tabular}

Note. ${ }^{*}$ Significant difference by Student's $\mathrm{t}$ test $(\mathrm{p}>0.01)$ between treatments (caged area and open area); ${ }^{\mathrm{ns}}$ Difference not significant by Student's t test $(p>0.01)$ between treatments (caged area and open area).

The production of grains divided by plant thirds also differed between the two treatments (with and without voile). In all evaluations, significant differences in grain yield were detected in each the three thirds analyzed in the uncovered area samples, which were exposed to flower-visiting insects (Table 1).

In the Bt cultivar, there was a (statistically insignificant) increase of $45.73 \%$ in the lower third, $115.73 \%$ in the middle third, and $81.32 \%$ in the upper third (the latter two with statistical significant at $1 \%$ probability level). The middle and upper thirds of the plant were responsible for $79.07 \%$ and $84.19 \%$ of the production in covered and flower-visitor-exposed plants, respectively. In the non-Bt cultivar, there was also a significant difference in grain yield in the thirds of the plants exposed to flower visitors. In the lower third, there was a $165.29 \%$ increase, while in the middle and upper thirds, the increases amounted to 274.91 and $152.39 \%$, respectively. In the same cultivar, production was also concentrated in the upper and middle thirds, corresponding to $81.87 \%$ and $84.10 \%$ of the production in the covered and exposed plants, respectively (Table 1).

The increase in the number of pods in the Intacta cultivar was $45.72 \%$ (from 39.33 pods/replicate in the covered area to 57.32 pods/replicate in the exposed area) and $101.25 \%$ (from 24.22 pods in the treatment with voile to 48.10 pods in the treatment without voile) in the Potência cultivar (Table 2). Taking the pod production of both cultivars together, samples protected from flower-visiting insects had an average yield of 31.78 pods/sample. A $66.40 \%$ increase was observed in uncovered samples, as the average total production of these samples was 53.13 pods/sample.

When analyzing the production of pods per plant sections, at least $80 \%$ of the pods are found in the upper and middle thirds (Table 2). Generally, there was an increase in the number of pods produced in all plant sections in the uncovered area replicates. In the middle third, the largest increases in pod production were observed in treatments with voile. In the non-Bt cultivar, for example, the difference between the treatments was $120.60 \%$ (from $30.48 \mathrm{~g} /$ replicate in the treatment with cages to $67.24 \mathrm{~g} /$ replicate in the treatment without cages) (Table 2).

When comparing plant heights, there was an increase of $9.09 \mathrm{~cm} /$ plant $(102.28 \mathrm{~cm} /$ plant in the treatment with voile to $111.37 \mathrm{~cm} /$ plant in the treatment without voile); in the non-Bt cultivar, the difference was smaller, with an increase of $5.34 \mathrm{~cm} /$ plant $(86.90 \mathrm{~cm} /$ plant in the treatment with voile to $92.24 \mathrm{~cm} /$ plant in the treatment without voile). Taking together the results for both cultivars, the average height was $94.59 \mathrm{~cm}$ and $101.80 \mathrm{~cm}$ for voile-covered and uncovered plants, respectively (Table 2). 
Table 2. Average number of pods and plant height of soybean under two pollination treatments: with free visitation of insects (open area), and without visitation of insects (caged area)

\begin{tabular}{|c|c|c|c|c|c|c|}
\hline \multirow{2}{*}{ Part of the plant } & \multirow{2}{*}{ Cultivars } & \multicolumn{2}{|c|}{ Number of pods } & \multirow{2}{*}{ Increment (\%) } & \multicolumn{2}{|c|}{ Plant height } \\
\hline & & Caged area & Open area & & Caged area & Open area \\
\hline \multirow{3}{*}{ Lower Third } & Intacta & 23.4 & $27.8^{\mathrm{ns}}$ & 18.80 & - & - \\
\hline & Potência & 10.24 & $26.56^{*}$ & 159.37 & - & - \\
\hline & TOTAL & 17 & $27.76^{*}$ & 61.59 & - & - \\
\hline \multirow{3}{*}{ Middle Third } & Intacta & 46.6 & $80.16^{*}$ & 72.01 & - & - \\
\hline & Potência & 30.48 & $67.24^{*}$ & 120.60 & - & - \\
\hline & TOTAL & 38.94 & $74.82 *$ & 91.22 & - & - \\
\hline \multirow{3}{*}{ Upper Third } & Intacta & $48 \mathrm{~b}$ & $64.00^{*}$ & 33.33 & - & - \\
\hline & Potência & 29.28 & $47.08^{*}$ & 60.79 & - & - \\
\hline & TOTAL & 39.40 & $56.78^{*}$ & 39.85 & - & - \\
\hline \multirow{3}{*}{ Total } & Intacta & 39.33 & $57.32^{*}$ & 45.72 & 102.28 & $111.37^{*}$ \\
\hline & Potência & 24.22 & $48.10^{*}$ & 101.25 & 86.90 & $92.24 *$ \\
\hline & Total & 31.78 & $53.12 *$ & 66.40 & 94.59 & $101.80 *$ \\
\hline
\end{tabular}

Note. ${ }^{*}$ Significant difference by Student's t test $(\mathrm{p}>0.01)$ between treatments (caged area and open area). ${ }^{\mathrm{ns}}$ Difference not significant by Student's t test $(p>0.01)$ between treatments (caged area and open area).

\section{Discussion}

A large number of flower-visiting insects, besides the honey bee, were collected during the flowering period, indicating a significant diversity of these insects, which belonged mainly to the orders Hymenoptera, Diptera, and Coleoptera. These visitors were found in similar abundances in both the cultivars. Therefore, the composition of floral insect species in the uncovered treatment did not interfere with the results obtained for the production when comparing the two cultivars studied herein.

The uncovered area with floral visitors showed a significant increase in grain production when compared with the covered area $(\mathrm{p} \leq 0.05)$, wherein the flowers had no contact with flower-visiting insects. In the uncovered area, there was a considerable increase in the production for both cultivars. This increase is higher than that found by Moreti (1998), who observed an increase of 58.58\% in cultivar IAC 14, and Chiari et al. (2005), who reported a $61.38 \%$ increase in cultivar BRS 133. The significant increase observed in the present work in the area where flower-visiting insects were free to visit might result from the high number of pollinator insects present, since there was an A. mellifera beehive next to the sampling area, resulting in an effective increment in the occurrence of these insects.

Even though soybean is a crop with a high degree of self-pollination (Milfont et al., 2013) and is not dependent on biotic pollination for its production, the increased production yields provided by entomophilic pollination allowed the confirmation of the importance and efficiency of flower-visiting insects for this crop. The first studies on this topic (Piper \& Morse, 1910; Woodhause \& Taylor, 1913; Milum, 1940; Rubis, 1970) considered soybean an autogamous species that would not benefit from the presence of pollinators. However, recent studies have shown that auto-fertile plants have a significant increase in fruit and seed production when their self-pollination is assisted by animals (Klein et al., 2003; Rizzardo et al., 2012), which was explicitly demonstrated with the results obtained herein.

Regarding grain production in the different sections of the plants, the middle and upper thirds stood out in both cultivars, as compared with the lower third, they presented a higher production and greater increase in grain production in the treatment accessible to flower visitors. The observed increase in production in these sections stems from the fact that these parts of the plant naturally present higher production, and possibly because the flowers in these sections are visited more frequently by the pollinating insects than the flowers of the lower third.

The average number of pods per sample differed highly across treatments. Uncovered area plants supported significantly more pods than those in the covered area. The main difference between the treatments when analyzing the number of pods was in the Potência cultivar, which presented a considerable increase in the number of pods in the uncovered area, pointing out the important role of flower visitors in the recovery of the plants attacked by caterpillars, which was detected in this cultivar. This increase in the number of pods in plants visited by insects was significantly lower in the Bt crop, which showed a smaller increase in production, possibly due to the fact that this cultivar was not susceptible to the attack of foliage-stripping caterpillars. 
Although plant height did not differ much between the treatments with and without voile, this difference was statistically significant. The treatment without voile yielded higher height values for both cultivars, and the same was observed when the total plants of the two cultivars were analyzed. This difference was likely due to the covering of the plants with voile structures, which might have decreased, albeit minimally, the exposure of plants to solar rays. It is known that ecosystems are supplied with energy from an external source, usually the sun, and that the energy source affects plant development (Monteith, 1972).

Some flower visitors appear to be able to assist in a better placement or distribution of pollen grains over the surface of stigma (Yoshimura, 2011), which might increase grain yield or improve the quality of the grain produced. The role of flower visitors in the establishment of more or better grains or seeds in self-pollinated flowers has already been demonstrated in other plant species (Barret et al., 1994; Cruz et al., 2005), and more recently, positive associations between fruits and grains in dozens of crops around the world and the visitation of flowers by wild insects have been established (Garibaldi et al., 2013), which shows that pollination by introducing bees, as in the case of $A$. mellifera, has complemented native insect pollination.

Based on the results obtained in the present study, it is clear that one must identify native and introduced pollinators of soybean crops to adopt appropriate management practices aimed at the preservation and increase of the populations of flower visitors. Among these practices, it is fundamental to employ selective pesticides, to apply chemical insecticides only when pests reach the levels necessitating control, and also to avoid the spraying of insecticides during the flowering period, thus guaranteeing the presence of these insects in crops and improving productivity compared with areas with flower visitor deficits, which was represented in this experiment by the covered area.

\section{References}

Agrianual. (2009). Agrianual: Anuário da agricultura brasileira (12th ed., p. 516). São Paulo: IFNP.

Andow, D. (2008). The risk of resistance evolution in insects of transgenic insecticidal crops. Collection of Biosafety Reviews, 4, 142-199.

Barret, S. C. H., Harder, L. D., \& Cole, W. W. (1994). Effects of flower number and position on self-fertilization in experimental populations of Eichhornia paniculata (Pontederiacea). Functional Ecology, 8, 526-535. https://doi.org/10.2307/2390078

Carlson, J. B. (1973). Morphology. In B. E. Caldwell (Ed.), Soybeans: Improvement, production and uses (pp. 17-95). Madison: American Society of Agronomy.

Charles, J. F., Nielsen-Leroux, C., \& Delecluse, A. (1996). Bacillus sphaericus toxins: Molecular biology and mode of action. Annual Review of Entomology, 41, 451-472. https://doi.org/10.1146/annurev.en.41.010196. 002315

Chiari, W. C. (2005). Floral biology and behavior of Africanized honeybees Apis mellifera in soybean (Glycine $\max$ (L.) Merrill). Brazilian Archives Biological Technology, Curitiba, 48, 367-378. https://doi.org/ 10.1590/S1516-89132005000300006

Chiari, W. C., Toledo, V. D. A. A. D., Ruvolo-Takasusuki, M. C. C., Oliveira, A. J. B. D., Sakaguti, E. S., Attencia, V. M., ... Mitsui, M. H. (2005). Pollination of soybean (Glycine max (L.) Merril by honeybees (Apis mellifera L.). Brazilian Archives Biological Technology, 48, 31-36. https://doi.org/10.1590/S1516-891 32005000100005

Cruz, D. O., Freitas, B. M., Silva, L. A., Silva, E. M. S., \& Bomfim, I. G. A. (2005). Pollination efficiency of the stingless bee Melipona subnitida on greenhouse sweet pepper. Pesquisa Agropecuária Brasileira, 40, 1197-1201. https://doi.org/10.1590/S0100-204X2005001200006

CTNBIO (Comissão Técnica Nacional de Biossegurança). (2010). Liberação comercial de soja MON $87701 \times$ MON 89788, que confere resistência a insetos e tolerância a herbicida, bem como todas as progênies dela provinientes, concluiu pelo Deferimento, nos termos deste parecer técnico n. 2.542/2010. Brasília, Brazil.

Embrapa. (2015). Soja em números, safra 2014/1015 (Comunicado Técnico). Embrapa-Soja, Londrina. Retrieved January 12, 2016, from https://www.embrapa.br/soja/cultivos/soja1/dados-economicos

Emrapa. (2005). BRS Carnaúba, nova cultivar de soja para a região Norte e Nordeste do Brasil (Comunicado Técnico 180). Embrapa-Meio Norte, Teresina.

Free, J. B. (1993). Insect pollination of crops (2nd ed.). University Press, Cardiff.

Freitas, B. M. (1997). Changes with time in the germinability of cashew (Anacardium occidentale) pollen grains 
found on different body areas of its pollinator bees. Revista Brasileira de Biologia, 57, 289-294.

Garibaldi, L. A., Steffan-Dewenter, I., Winfree, R., Aizen, M. A., Bommarco, R., Cunningham, A. S., Klein, A. M. (2013). Wild pollinators enhance fruit set of crops regardless of honeybee abundance. Science, 339, 1608-1611. https://doi.org/10.1126/science. 1230200

Hilder, V. A., \& Boulter, D. (1999). Genetic engineering of crop plants for insect resistance a critical review. Crop Protection, 18, 177-191. https://doi.org/10.1016/S0261-2194(99)00028-9

Jenkins, J. L., Lee, M. K., Sangadala, S., Adang, M. J., \& Dean, D. H. (1999). Binding of Bacillus thuringiensis CrylAc toxin to Manduca sexta aminopeptidade-N receptor is not directaly related to toxicity. FEBS Letters, 462, 373-376. https://doi.org/10.1016/S0014-5793(99)01559-8

Justiniano, W., Fernandes, M. G., Viana, C. L. T. P., \& Fonseca, P. R. B. (2014). Intacta RR2PRO (MON87701 × MON89788) for Management of the Main Target and Non-Target Insects in Soybeans. Journal of Agricultural Science, 6(2), 33-44. https://doi.org/10.5539/jas.v6n2p33

Klein, A. M., Steffan-Dewenter, I., \& Tscharntke, T. (2003). Bee pollination and fruit set of Coffea arabica and C. canephora (Rubiaceae). American Journal of Botany, 90, 153-157. https://doi.org/10.3732/ajb.90.1.153

McGregor, S. E. (1976). Insect pollination of cultivated crop-plants. USDA Agriculture Handbook (Vol. 496, pp. 93-98). Retrieved from http://gears.tucson.ars.ag.gov/book

Milfont, M. O., Rocha, E. E. M., Lima, A. O. N., \& Freitas, B. M. (2013). Higher soybean production using honeybee and wild polinators, a sustainable alternative to pestices and autopollination. Environmental Chem Letters, 11, 335-341. https://doi.org/10.1007/s10311-013-0412-8

Milum, V. G. (1940). Bees and soybeans. American Bee Journal, 80, 22.

Monsanto. (2011). Maximizing soybean yield potential. Agronomic spotlight. Monsanto Technology Development. Retrieved from http://www.renkseed.com/Portals/0/Agronomic\%20Spotlight\%20-\%2b0Max imizing\%20Soybean\%20Yield\%20Potential.pdf

Monteith, J. L. (1972). Solar radiation in productivity in tropical ecosystems. Journal of Applied Ecology, 9 , 747-766. https://doi.org/10.2307/2401901

Moreti, A. C. C. C. (1998). Observações sobre a polinização entomófila da cultura da soja (Glycine max (L.) Merrill). Boletim da Industria Animal, 55, 91-94.

Nogueira-Couto, R. H. (1994). Polinização com abelhas africanizadas (pp. 101-117). Encontro Sobre Abelhas, 1994, Anais... Faculdade de Filosofia Ciências e Letras, Ribeirão Preto.

Nogueira-Couto, R. H. (1998). Manejo das colméias de abelhas africanizadas para polinização (pp. 129-134). Congresso Brasileiro de Apicultura, 12, 1998, Salvador. Anais... Salvador: Confederação Brasileira de Apicultura.

Piper, C. V., \& Morse, W. J. (1910). The soybean: history, varieties and field studies. USDA Plant Ind. Bull., Urbana, 197, 1-84.

Rizzardo, R. A. G., Milfont, M. O., Silva, E. M. S., \& Freitas, B. M. (2012). Apis mellifera pollination improves agronomic productivity of anemophilous castor bean (Ricinus communis). Anais da Academia Brasileira de Ciências, 84, 605-608. https://doi.org/10.1590/S0001-37652012005000057

Rubis, D. D. (1970). Breeding insect pollinated crops. Little Rock (Vol. 127, pp. 19-24). Arkansas Agriculture Extension Service, USA.

Sankula, S. (2006). Crop Biotechnology in the United States: Experiences and impact. In N. G. Halford (Ed.), Plant Biotechnology (pp. 29-52). John Wiley \& Sons Ltda. https://doi.org/10.1002/0470021837.ch2

Sharma H. C., Sharma, K. K., Seetharama, N., \& Ortiz, R. (2000). Prospects for using transgenic resistance to insects in crop improvement. Electronic Journal of Biotechnology, 2, 1-26. https://oi.org/10.2225/ vol3-issue2-fulltext-3

USSEC. (2008). How the global oilseed and grain trade works. USSEC, Saint Louis.

Williams, I. H. (1991). Beekeeping, wild bees and pollination in the European community. Bee World, Cardiff, 72, 170-180. https://doi.org/10.1080/0005772X.1991.11099101

Woodhause, E. J., \& Taylor, C. S. (1913). The varieties of soybeans found in Bengal, Bihar and Orissa and their commercial possibilities. Mem. Dep. Agric. India, Bot. Ser., 5, 103-175. 
Yoshimura, Y. (2011). Wind tunnel and field assessment of pollen dispersal in soybean [Glycine max (L.) Merr.]. Journal of Plant Research, 124, 109-114. https://doi.org/10.1007/s10265-010-0357-y

Yu, H. L., Yun, H. L., \& Kong, M. W. (2011). Risk assessment and ecological effects of transgenic Bacillus thuringiensis crops on non-target organisms. Journal of Integrative Plant Biology, 53, 520-538. https://doi.org/10.1111/j.1744-7909.2011.01047.x

\section{Copyrights}

Copyright for this article is retained by the author(s), with first publication rights granted to the journal.

This is an open-access article distributed under the terms and conditions of the Creative Commons Attribution license (http://creativecommons.org/licenses/by/4.0/). 